\title{
AN EXPLORATIVE STUDY ON THE SUITABILITY OF SESAME PLANT MUCILAGE (SESAMUM INDICUM) AS ADMIXTURES IN CONCRETE
}

\author{
Alaku Paul Orame \\ Graduate student University of Jos, Plateau, Nigeria \\ Agboola Shamsudeen Abdulazeez, Musa Abdulhakeem Kolawole \\ M.Tech Student, Abubakar Tafawa Balewa University Bauchi, Nigeria
}

\begin{abstract}
Concrete consist of cement, aggregates and water, with any other admixtures added to improve or modify the placing and process of curing or other properties. These days concrete are applicable for extensive purposes. For these reasons, ordinary concrete may fail to exhibit the quality performance required. In such cases, admixtures are used in modifying the properties of ordinary concrete in order to make it more suitable for any situation and applications. This paper presents the experimental result on the explorative study of sesame plant mucilage as an admixture in concrete. The study was conducted through experimental research approach whereby laboratory experiments were carried out and result presented, after which conclusion and recommendation followed. Chemical composition of Sesame mucilage as well as the workability, compressive strength split tensile strength and flexural strength properties of varying percentage of Sesame mucilage at $1.0 \%, 1.5 \%$ and $2.0 \%$ as admixture in concrete and $100 \%$ cement concrete of mix ratio 1: 1.84: 2.88 and watercement ratio of 0.6 were examined and compared. Slump test and compacted factor test was carried out to check the effect of Sesame mucilage on the workability of fresh concrete. The concrete were tested at the curing ages of 7, 14 and 28 days. The results showed that Sesame mucilage has a combined $\mathrm{SiO}_{2}, \mathrm{Al}_{2} \mathrm{O}_{3}$ and $\mathrm{Fe}_{2} \mathrm{O}_{3}$ composition of $25.58 \%$. The result shows that at 28 days all admixture percentage has higher compressive strength than control concrete with $33.2 \mathrm{~N} / \mathrm{mm}^{2}, 31.3 \mathrm{~N} / \mathrm{mm}^{2}$ and $30.8 \mathrm{~N} / \mathrm{mm}^{2}$ for $1.0 \%, 1.5 \%$ and $2.0 \%$ percentage admixture respectively, as compared to plain concrete which was $28.0 \mathrm{~N} / \mathrm{mm}^{2}$. The result also shows that percentage admixture has higher flexural and split tensile strength than control concrete at all curing ages. The strength test results indicated that Sesame mucilage as admixture in concrete gave better strength compared to control samples. A $1.5 \%$ replacement of cement with Sesame mucilage was found
\end{abstract}

convincing and indicate the optimum percentage admixture in concrete mix. However can be used up-to 2.0\% admixture level due to its higher strength as compared to the control mix. The research recommends use of Sesame mucilage as an admixture in concrete production.

Keywords - Chemical Properties, Workability, Compressive Strength, Split Tensile Strength, Flexural Strength, Sesamum Indicum (sesame plant mucilage)

\section{INTRODUCTION}

Concrete is the most widely used material in construction with cement as it binder. It is a composite mixture of cement, coarse aggregate, fine aggregate and water in required proportion and added admixture. For several years, concrete have been used in building and civil engineering works because of its strength and durability, therefore it is faced with series of problem that includes reduced workability, segregation, plastic and hardened strength [1]. Several research works are been carried out recently in order solve these problems and as such keeping in mind tremendous improvement in concrete production. Recent days, concretes are produce to meet diverse target in different conditions. To fend for concrete in conditions where ordinary concrete may fail to exhibit the required quality strength and durability, admixtures are use to modify the properties of ordinary concrete in order to make it more suitable for any kind of situation [2]. Admixtures are included in concrete to improve the quality of concrete. According to [3] admixtures are chemicals added to concrete during mixing, immediately after mix or after the mix have hardened. They can be a single chemical or a blend of several chemicals and may be in form of powders, or as aqueous solutions because in this form they are easier to accurately dispense into, and then disperse through the concrete. 


\section{International Journal of Engineering Applied Sciences and Technology, 2020 \\ Vol. 4, Issue 11, ISSN No. 2455-2143, Pages 574-581 \\ Published Online March 2020 in IJEAST (http://www.ijeast.com)}

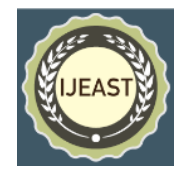

Admixtures are materials other than the basic ingredients of concrete which are cement, water, fine aggregate, coarse aggregate and reinforcement which are added to the batch immediately before or during mixing with aim of changing some of the properties [4]. [5] Further explains admixtures as materials other than water, aggregates, and hydraulic cements used as an ingredient of concrete or mortar and added to the batch immediately before or during mixing. The use of admixtures is accompanied with various advantages which includes improved quality, coloring, greater concrete strength, increased flow for the same water-cement ratio, enhanced frost, resist ingress of chemicals, improved fire resistance, cracking control, acceleration or retardation in setting time and improved workability [6]. Typically, there are two admixtures: chemical admixtures and mineral admixtures. Chemical admixtures consist of accelerators, retarders, super plasticizing admixtures, air entraining admixtures, water reducing admixtures while pozolanna admixtures, grouting admixtures, water proofing admixture, bonding admixtures, air detraining admixtures, colouring admixtures are mineral admixtures [7]. Mineral admixture thus increases the slump, compacting factor and delay the initial and final setting [8]. Mineral admixtures also serve to decrease the cost of concrete mix and to improve the workability of fresh concrete. In addition, fresh concrete mixtures containing mineral admixtures are less prone to bleeding [9]. One of the many different admixtures may be the sesame plant extract. Which are economical, easy to obtain and environmental-friendly, sustainable, and these locally produced plants can be grown found in many cities of Nigeria. Sesame plants is grown in many parts of the world; the largest producer of the crop was India, China, Myanmar, Sudan, Ethiopia, Uganda and Nigeria; however, twenty-six percent of these crops are grown in Africa [10]. Sesame was widely grown in Middle Belt, Northern and Central Nigeria as a minor crop initially in 1974 when it became a major cash crop in many Northern States, which includes Benue, Kogi, Gombe, Jigawa, Kano, Nasarawa, Katsina, Plateau, Yobe and Federal capital Territory [11].

Sesamum is an annual flowering plant growing 50 to $100 \mathrm{~cm}$ (1.6 to $3.3 \mathrm{ft}$ ) tall. The flower varies in colour with some being white, blue or purple. The fruit naturally splits opens to release the seeds by splitting along the septa from top to bottom or by means two apical pores, depending on the varietals cultivars. The most important part of Sesame plants are the leaves and seeds [12]. Sesame has compounds like sesamin, sesaminol, gamma tocopherol, cephalin and lecithin. These compounds impart many of the pharmacological activities like antioxidant, antibacterial, cardio tonic, antidiabetic, hypocholesterolemic, antitumor, antiulcer, anti-inflammatory and analgesic to sesame [13]. Other types of admixture include fly-ash, rice husk ash, silica fume and ground granulated blast furnace slag. However little or no application in the technology of sesame plant in construction and concrete field were studied.

Nigeria has a great market potential for sesame seed production for domestic and export markets noting that the production figures of the commodity has been on a steady increase since 1980, reaching 67000 MT by 1997 and was estimated to reach 139,000 MT by the year 2010, according to the federal ministry of agriculture and natural resources [14]. This is agreement with the 2008 annual report of the Central Bank of Nigeria which states there has been a rise in production of sesame seed from $98,000,000$ to $152,000,000 \mathrm{~kg}$ from 2003 to 2007 [15].

Although, the application of sesame plant in pharmacy and other related medical field is advanced but the gum produced from its materials has been neglected. The gum produced from this plant becomes waste presenting little or no benefit to the populace and not been utilized for any purpose. However, there is need to carry out researches to determine how the use of sesame plant mucilage (sesamum indicum) as admixtures can improve the properties of concrete and can be of great benefits and significance to the construction industry as a whole and the Nigeria construction sector.

\section{MATERIALS AND METHODS}

All the materials used for laboratory experiment were source from the immediate environment. The materials used for this study include Cement, fine aggregate, coarse aggregate, water and Sesamum plant mucilage extracted from sesame plant. The cement used in this research is Bua ordinary Portland cement (OPC), of grade 42.5 procured from a local supplier of cements at Katako junction, Jos north, plateau state. The fine aggregate used was river sharp, free from impurities, which passed through $4.75 \mathrm{~mm}$ sieve and are gotten from bauchi road, opposite Joshua Dariye park, Jos north, plateau state. Coarse aggregate used was obtain from a local crushing plant at Bauchi ring road, jos north, plateau state. It was in saturated surface dry condition and was also sieved to pass through $20 \mathrm{~mm}$ sieve and retained on $10 \mathrm{~mm}$ sieve. Bore hole water sourced within university of Jos permanent site was used for the research. Fresh sesame plant was obtained from Farin gada market, Jos north in plateau state.

Sesamum Mucilage Extractions: Sesamum mucilage is extracted from sesame plant (sesamum indicum). The plant is wash to remove impurities then dries to remove water, after drying the plant is cut into smaller sizes to allow easy handling of the plant, the plant is then soak in a pan with small quantity of water, depending on the amount of plant to be used. The plant is squeezed, after squeezing it will then be sieved to extract the mucilage in the form of a paste. Ethanol is then added to the mucilage, which turn the pastry nature to solid form. Ethanol added again to remove any water left in the solid, and the mucilage is dried at room temperature. After drying, the solid then pulverized into powdery form and use for the intended purpose. The process id presented in Plate 16.

Chemical Analysis of Materials: The chemical analysis test of the sesame plant mucilage (sesamum indicum) was carried out at the Department of Chemistry, Nigerian institute of 


\section{International Journal of Engineering Applied Sciences and Technology, 2020 \\ Vol. 4, Issue 11, ISSN No. 2455-2143, Pages 574-581 \\ Published Online March 2020 in IJEAST (http://www.ijeast.com)}

Mining and Geoscience, Tudun wada, Jos north, Plateau state, in order to determine the oxide composition of the sesame plant mucilage sample.

Workability: The Compacting factor test was conducted in accordance with [16]. Slump test was also conducted using the relevant cone for measurements, the tests was conducted in accordance with [26].

Compressive Strength Test: The compressive strength test was conducted in accordance with [17]. The ratio of admixture is $1 \%, 1.5 \%$, and $2 \%$. The cubes were cast and cured for 7 days, 14 days and 28 days respectively. For each mix, 3 cubes were crushed to obtain the average strength of the concrete samples. The compressive strength is the ratio of the weight of cube and the cross sectional area. The formula is presented in equation 1.

$\frac{\operatorname{Load}(N)}{\text { Loading Area }(\mathrm{mm} 2)}$

Flexural Strength of Concrete: In the determination of flexural strength of concrete beams, the procedure followed was in accordance with [18]. 3 beams were cast for each mix and cured for 7 and 28 days respectively. There specimens were crushed to obtain the average strength of the concrete samples and the maximum load was recorded. The formula used is shown in equation 2.

$\mathbf{R}=\frac{\mathbf{M c}}{\mathbf{I}}=\frac{\mathbf{P L}}{\mathbf{b d}^{2}}$.

$\mathrm{R}=$ flexural strength $\left(\mathrm{n} / \mathrm{mm}^{2}\right)$,

$\mathrm{I}=$ moment of inertia $\left(\mathrm{mm}^{4}\right)$,

$\mathrm{P}=$ failure load $(\mathrm{n})$

$\mathrm{M}=$ max. bending moment (nmm),

$\mathrm{L}=$ length $(\mathrm{mm})$,

$\mathrm{b}=$ average width $(\mathrm{mm})$,

$\mathrm{c}=\mathrm{d} / 2(\mathrm{~mm})$,

$\mathrm{d}=$ average depth $(\mathrm{mm})$

Splitting Tensile Strength Test: According to [19], tensile strength of concrete is determined by indirect method since it was very difficult to apply uniaxial tension to a concrete specimen. The splitting tensile strength was carried out using the compressive universal testing machine of $2000 \mathrm{KN}$ capacity. The splitting tensile strength formula is presented in equation 3;

$\mathrm{ft}=\frac{2 \mathrm{p}}{\pi \mathrm{Ld}}$

Where:

$\mathrm{ft}=$ splitting tensile strengths $\left(\mathrm{N} / \mathrm{mm}^{2}\right)$

$\mathrm{P}=$ failure load $(\mathrm{KN})$

$\mathrm{d}=$ diameter of cylinder $(\mathrm{mm})$

$\mathrm{l}=$ lenght of cylinder $(\mathrm{mm})$

\section{RESULTS AND DISCUSSION}

Chemical Analysis: The result of the oxide composition as presented in Table 1, shows that sesamum mucilage consist of $20.60 \%$ Silicon Oxide $\left(\mathrm{SiO}_{2}\right), 4.15 \%$, Aluminum Oxide $\left(\mathrm{Al}_{2} \mathrm{O}_{3}\right), 1.10 \%$ Iron Oxide $\left(\mathrm{Fe}_{2} \mathrm{O}_{3}\right)$ 1.65\% Calcium Oxide $(\mathrm{CaO})$, and $0.85 \%$ Magnesium Oxide $(\mathrm{MgO})$. However the most important and significant constituents for any mineral admixture are silica and alumina oxides are present in sesamum mucilage though aluminum is present in small percentage. Sesamum mucilage has substantial contents of silica and alumina oxide showing its capability to produce calcium silicate hydrate (CSH) and calcium aluminate hydrate $(\mathrm{CAH})$ which has bonding characteristics in the concrete.

Workability: The Slump test result is presented in Figure 1.The slump values increased with increase ratio of sesamum mucilage content. According to [20], 0\% admixture was in the S1 classification $(10 \mathrm{~mm}-40 \mathrm{~mm})$ while the remaining of $1 \%$, $1.5 \%$ and $2 \%$ replacement were in the S2 classification $(50 \mathrm{~mm}-90 \mathrm{~mm})$. The result of the Compacting factor test is shown in Figure 2. The values increased with the increase in the proportion of sesamum mucilage content and with highest value at $2 \%$ cement replacement, unless for $1.0 \%$ admixture which was lesser than $0 \%$ admixture. However this result further confirmed the use of sesamum mucilage as possessing admixture characteristics. The Compacting factor values can be categorized as very low $(0.78)$, low $(0.85)$, medium $(0.92)$ and high (0.95) as specified by [21].

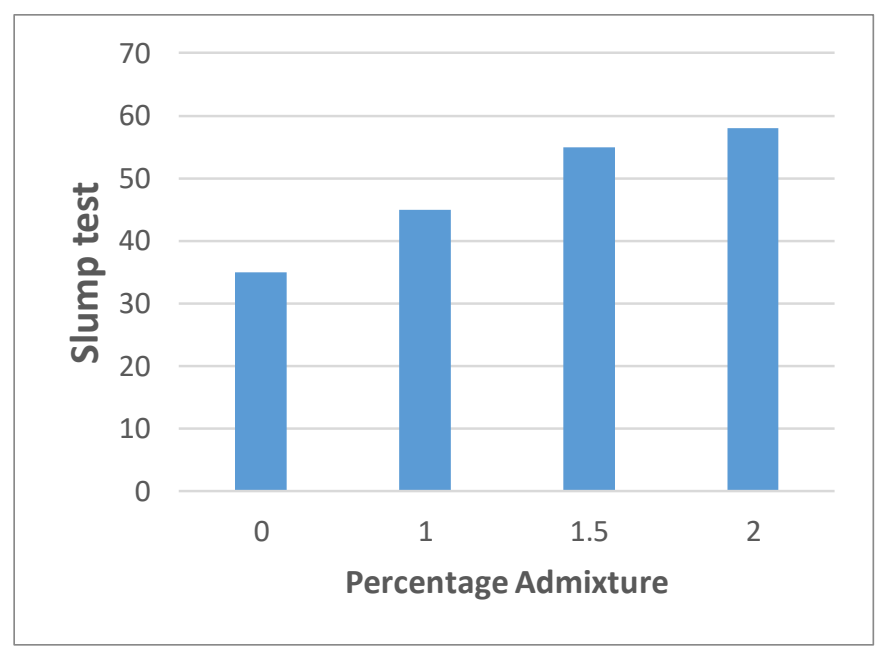

Fig. 1: Slump test 
International Journal of Engineering Applied Sciences and Technology, 2020

Vol. 4, Issue 11, ISSN No. 2455-2143, Pages 574-581

Published Online March 2020 in IJEAST (http://www.ijeast.com)

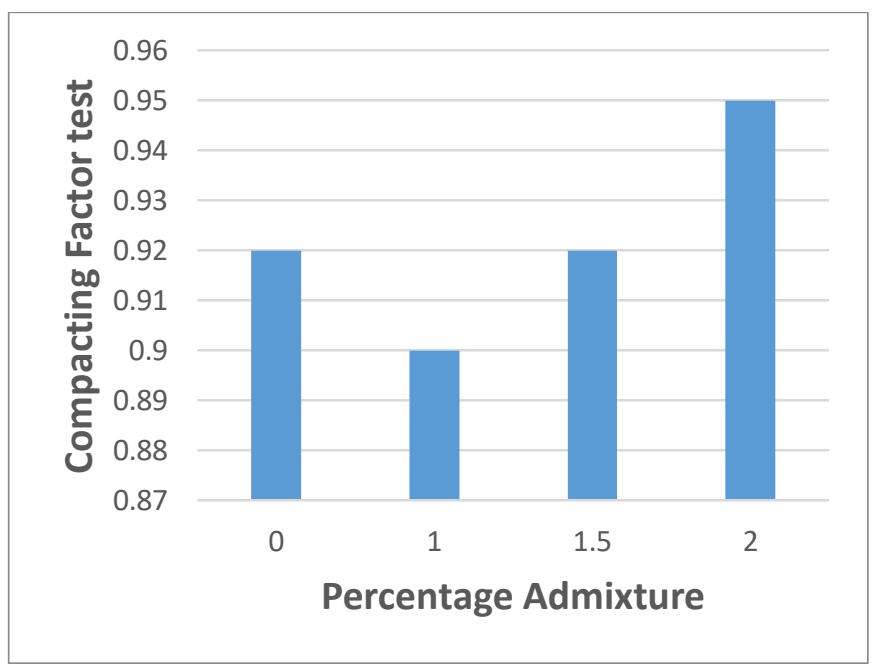

Fig. 2: Compacting Factor test

Density of Hardened concrete: The results of all the 4 mixes of density of control concrete and concrete prepared with sesamum mucilage addition to concrete is presented in Figure $3-5$. The result shows that the density of hardened concrete is increased with addition of sesamum mucilage in concrete from $(1 \%-1.5 \%)$ but above $1.5 \%$ the density is reduced as compared to the control concrete. At 7 days $1.0 \%$ and $1.5 \%$ admixture in concrete cube has increased density of $4.99 \%$ as compared to the control concrete, while $2.0 \%$ admixture is less than the control concrete specimen. At 14 days all the admixture addition percentage has higher density than the control concrete. At 28 days the $1.5 \%$ admixture addition in concrete cubes has increased density of $7.34 \%$ as compared to the control concrete cubes. In addition the density of concrete is related to the strength of concrete, the higher the density the better the strength of concrete element. For the density of beam, at 7 days all the percentage addition of admixture has higher density than the control beam density, while at 28 days $1.0 \%$ of admixture has increased density of $3.58 \%$ as compared to the control beam density, while the control beam density is higher than other percentage admixture. The disparity in the result of the beam density of 28 days curing as to not in flow with the 7 days curing can be attributed to the inconsistency in the mixing and compaction of the concrete mixes. Furthermore, for cylindrical density, at 28 days the density of the entire percentage admixture is higher than the control concrete.

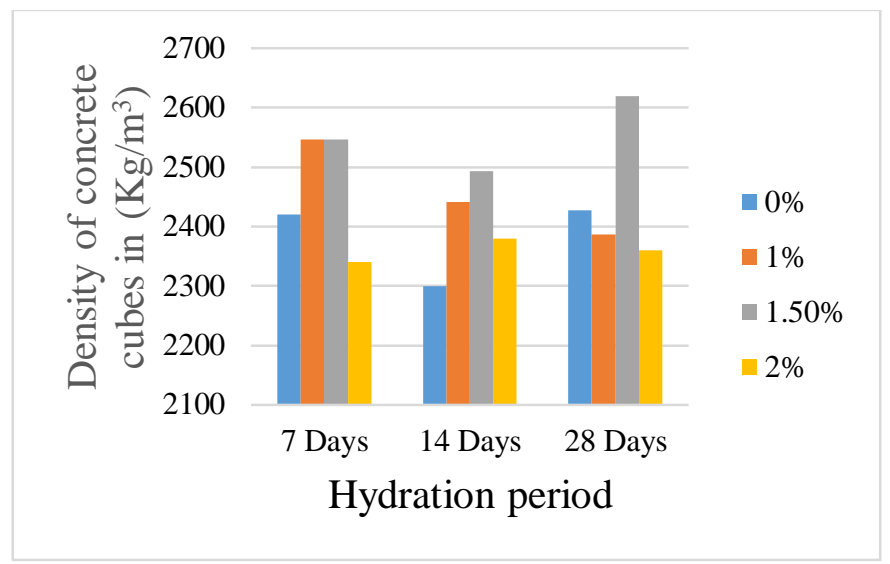

Fig. 3: Density of concrete cubes

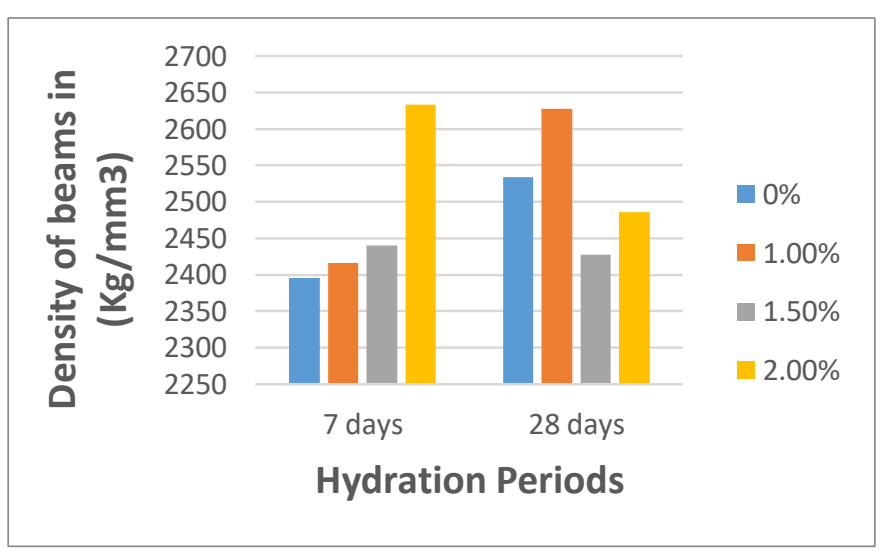

Fig. 4: Density of concrete Beam

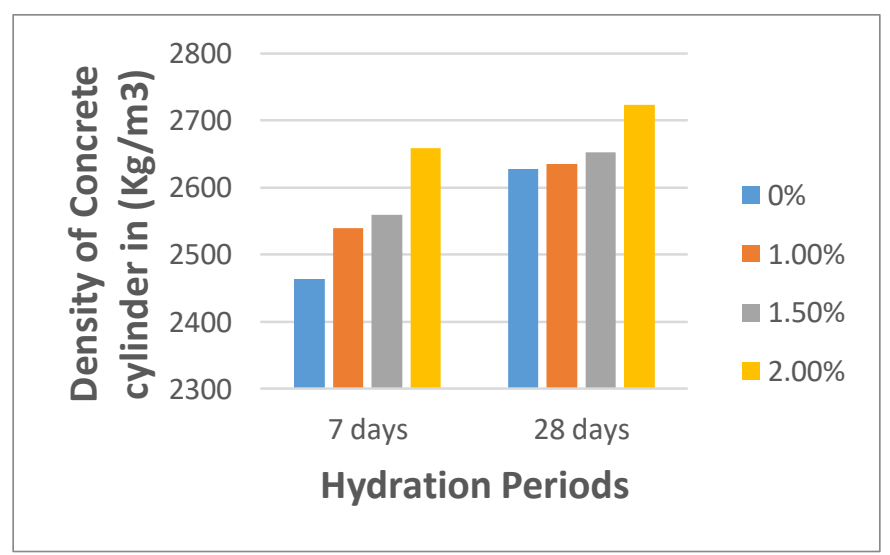

Fig. 5: Density of concrete Cylinder

Compressive strength: The results of the compressive strength test are shown in Figure 6. At 7 days the result shows increased compressive strength from $1 \%$ to $2 \%$ percentage admixture with sesamum mucilage as compared to $0 \%$ control concrete, which shows increase in strength of $2.53 \%$ at $1 \%$ admixture inclusion, $20.2 \%$ strength increase at $1.5 \%$ 


\section{International Journal of Engineering Applied Sciences and Technology, 2020 \\ Vol. 4, Issue 11, ISSN No. 2455-2143, Pages 574-581 \\ Published Online March 2020 in IJEAST (http://www.ijeast.com)}

admixture addition, and $11.1 \%$ increase in strength at $2.0 \%$ addition of admixture as compared to $0 \%$ addition of admixture. At 14 days the result shows increase in strength of $2.24 \%$ at $1 \%$ admixture inclusion, $15.5 \%$ strength increase at $1.5 \%$ admixture addition, and $6.44 \%$ increase in strength at $2.0 \%$ addition of admixture. At 28 days the result shows increase in strength of $10.54 \%$ at $1 \%$ admixture inclusion, $15.7 \%$ strength increase at $1.5 \%$ admixture addition, and $9.1 \%$ increase in strength at $2.0 \%$ addition of admixture This can be confirmed with the work [22] which says admixture significantly improves strength of concrete with time. However, $1.5 \%$ sesamum mucilage is the optimum admixture addition.

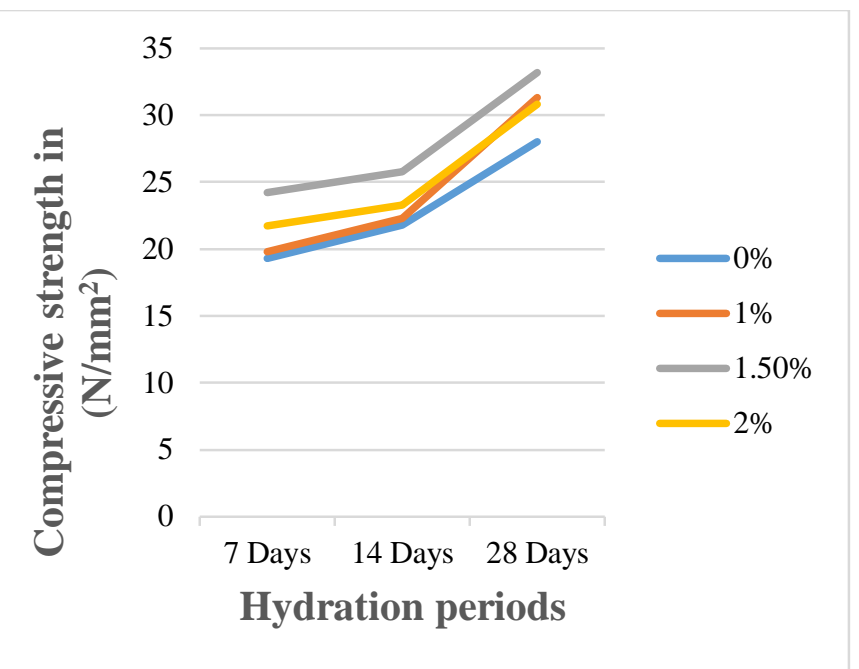

Fig. 6: Compressive strength of concrete

Flexural strength: The results of the flexural strength test are shown in Figure 7. The flexural strength was tested at 7 and 28 days only. At 7 days the result shows increased flexure strength from $1 \%$ to $2 \%$ percentage admixture of concrete with sesamum mucilage as compared to $0 \%$ control concrete. The result shows increase in strength of $5.46 \%$ at $1 \%$ admixture inclusion, $8.26 \%$ strength increase at $1.5 \%$ admixture and $6.88 \%$ increase in strength at $2.0 \%$ admixture as compared to $0 \%$ plain concrete. At 28 days the result shows increase in strength of $1.31 \%$ at $1 \%$ admixture inclusion, $8.52 \%$ strength increase at $1.5 \%$ admixture addition, and $5.45 \%$ increase in strength at $2.0 \%$ addition of admixture. However the optimum sesamum mucilage addition is $1.5 \%$.

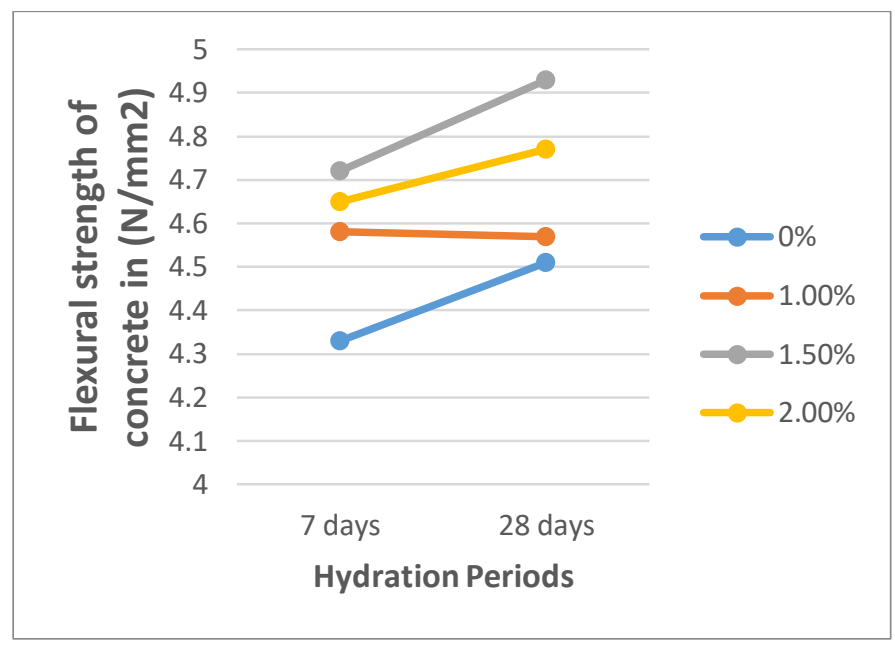

Fig. 7: Compressive strength of concrete

Split tensile strength

The result of the split tensile strength is presented in Figure 8. The split strength was tested at 7 and 28 days only. At 7 days the result shows increased tensile strength from $1 \%$ to $2 \%$ percentage admixture of concrete with sesamum mucilage as compared to $0 \%$ control concrete. The result shows increase in strength of $3.56 \%$ at $1 \%$ admixture inclusion, $11.73 \%$ strength increase at $1.5 \%$ admixture addition, and $5.24 \%$ strength increase at $2.0 \%$ addition of admixture as compared to $0 \%$ addition of admixture. At 28 days, the result shows increase in tensile strength of $1.47 \%$ at $1 \%$ admixture inclusion, $11.41 \%$ strength increase at $1.5 \%$ admixture and $4.57 \%$ increase in strength at $2.0 \%$ addition of admixture. However the optimum sesamum mucilage addition is $1.5 \%$.

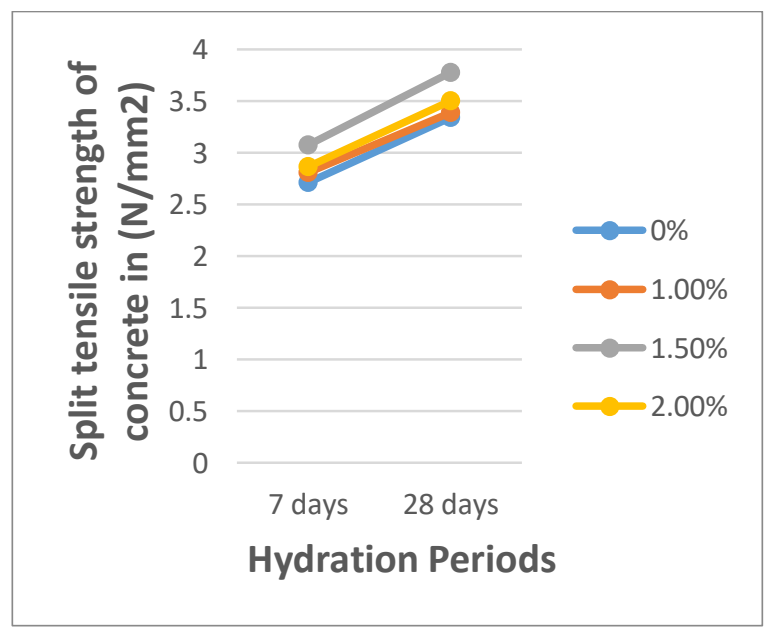

Fig. 8: Split tensile strength of concrete 


\section{International Journal of Engineering Applied Sciences and Technology, 2020 \\ Vol. 4, Issue 11, ISSN No. 2455-2143, Pages 574-581 \\ Published Online March 2020 in IJEAST (http://www.ijeast.com)}

\section{CONCLUSION}

Base on the conducted research it can be concluded that: Workability of concrete is increases as the dosage of sesamum mucilage is increasing. The maximum increase in workability was observed at $2.0 \%$ percentage addition of sesamum mucilage in concrete mix. The result shows that the workability of the concrete depend on the percentage admixture used in the mix. Density of hardened concrete is increased with percentage addition of sesamum mucilage upto $1.5 \%$ for concrete cubes, while for beams and cylinder the density of all percentage addition of admixture is higher than that of plain concrete. Compressive strength of concrete is increased with percentage addition of admixture with sesamum mucilage at all percentage inclusion. Also for flexural beams, all percentage addition of sesamum mucilage has increased strength than control concrete. The result also shows higher tensile strength at all percentage addition of sesamum mucilage as compared to control concrete. It was observed that the optimum percentage is at $1.5 \%$ admixture addition in concrete with sesamum mucilage. In addition, the presence of sesamum mucilage increases the cohesiveness of the concrete mix. The research recommends that sesamum mucilage should be use in the construction industry to improve the properties of concrete. Further research be carried out using sesamum mucilage as a pozollanic material in concrete and can be used with other pozollanic material with higher silica content to see their suitability and reactivity. Other mix ratio be designed and use for concrete mix. Varying water cement ratio could be use for concrete mix. The sesamum plant be classified according to types and region to determine is reactivity and chemical constituent of the plant.

Table1: Chemical analysis of sesame plant mucilage

\begin{tabular}{ll}
\hline Elements & $\begin{array}{l}\text { (\%) } \\
\text { composition }\end{array}$ \\
\hline Silicon Oxide $\left(\mathrm{SiO}_{2}\right)$ & 20.60 \\
Aluminum Oxide $\left(\mathrm{Al}_{2} \mathrm{O}_{3}\right)$ & 4.15 \\
Iron Oxide $\left(\mathrm{Fe}_{2} \mathrm{O}_{3}\right)$ & 1.10 \\
Titanium Oxide $\left(\mathrm{TiO}_{2}\right)$ & $\mathrm{N} . \mathrm{D}$ \\
Calcium Oxide $(\mathrm{CaO})$ & 1.65 \\
Magnesium Oxide $(\mathrm{MgO})$ & 0.85 \\
Sodium Oxide $\left(\mathrm{Na}_{2} \mathrm{O}\right)$ & 0.06 \\
Potassium Oxide $\left(\mathrm{K}_{2} \mathrm{O}\right)$ & 0.22 \\
Loss on Ignition $(\mathrm{LOI})$ & 70.52 \\
\hline
\end{tabular}

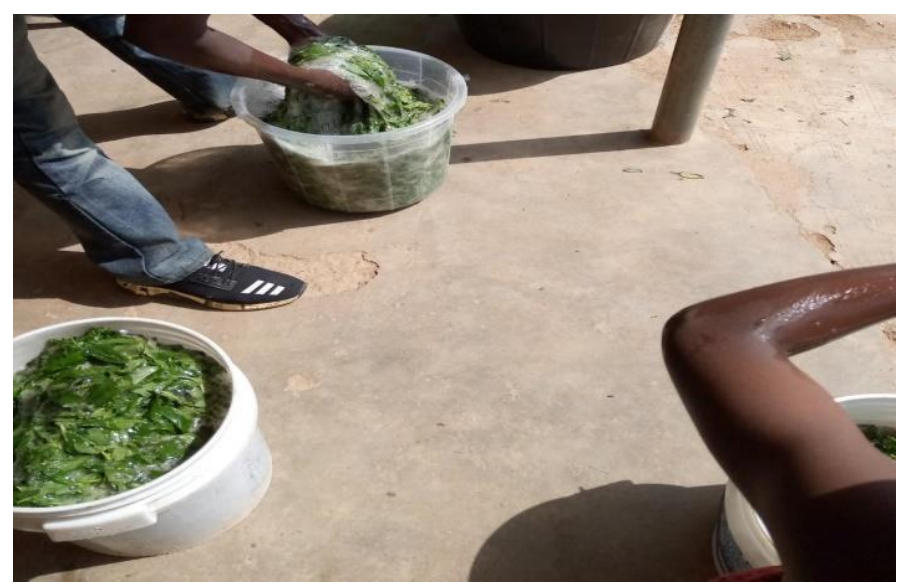

Plate 1: Adding water sesamum plant and squeezing

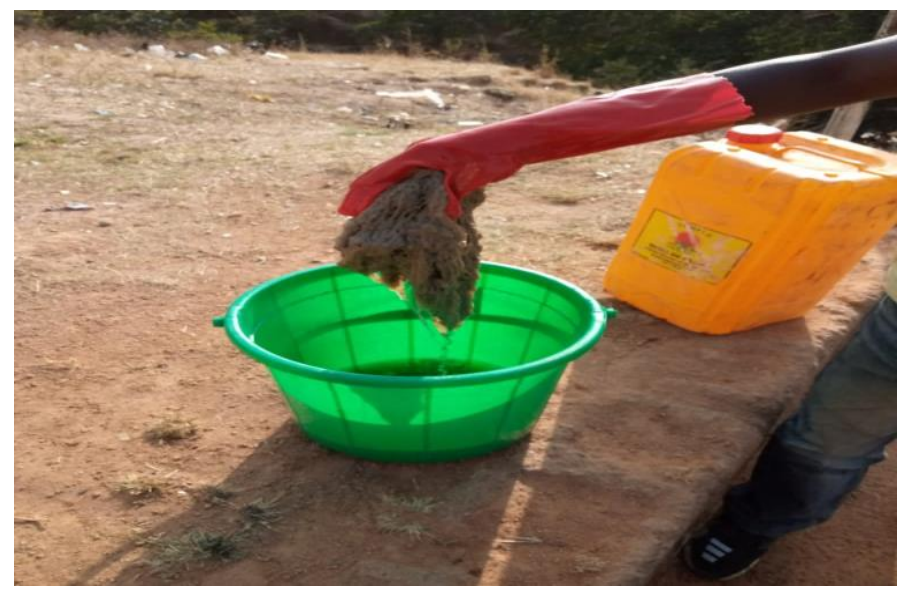

Plate 2: Sieved mucilage and adding ethanol

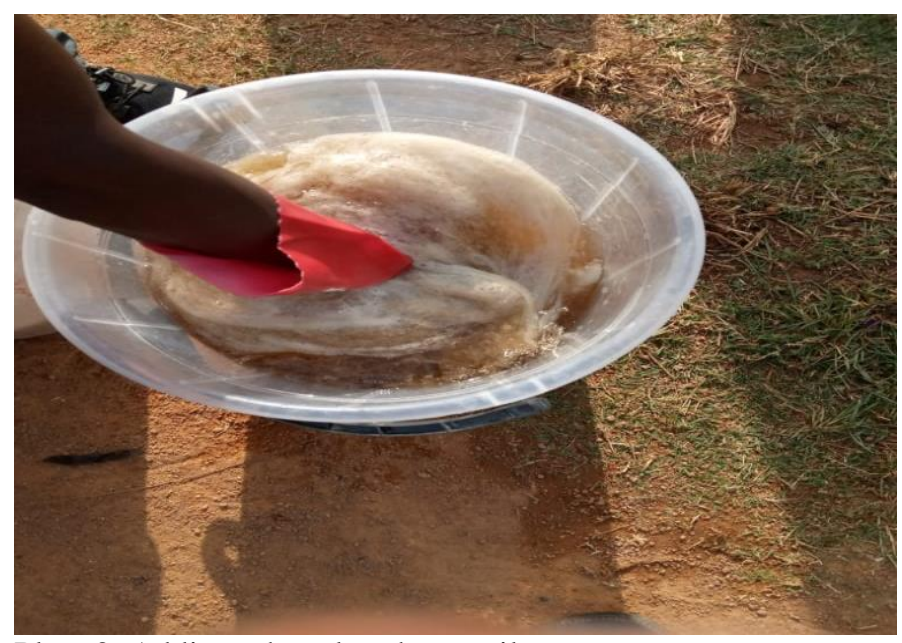

Plate 3: Adding ethanol to the mucilage 


\section{International Journal of Engineering Applied Sciences and Technology, 2020 \\ Vol. 4, Issue 11, ISSN No. 2455-2143, Pages 574-581 \\ Published Online March 2020 in IJEAST (http://www.ijeast.com)}

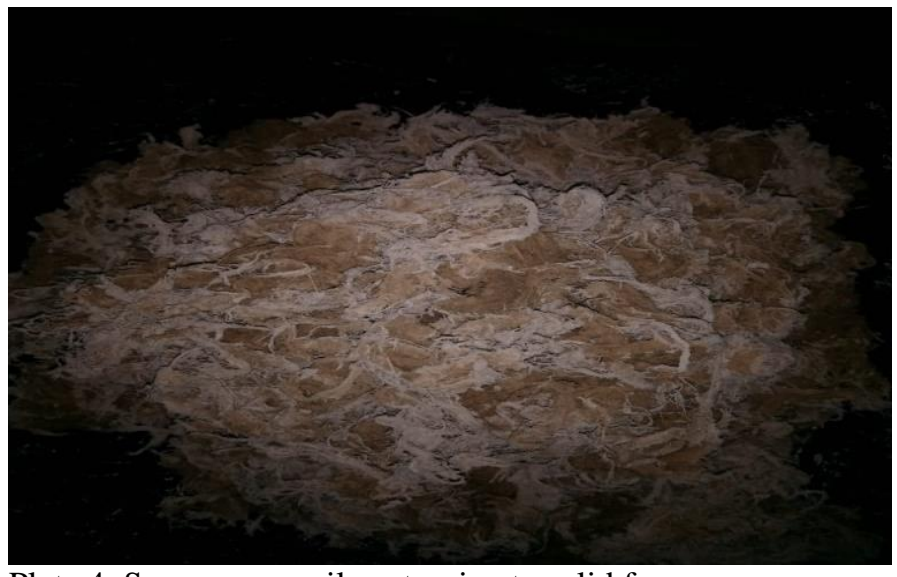

Plate 4: Sesamum mucilage turning to solid form

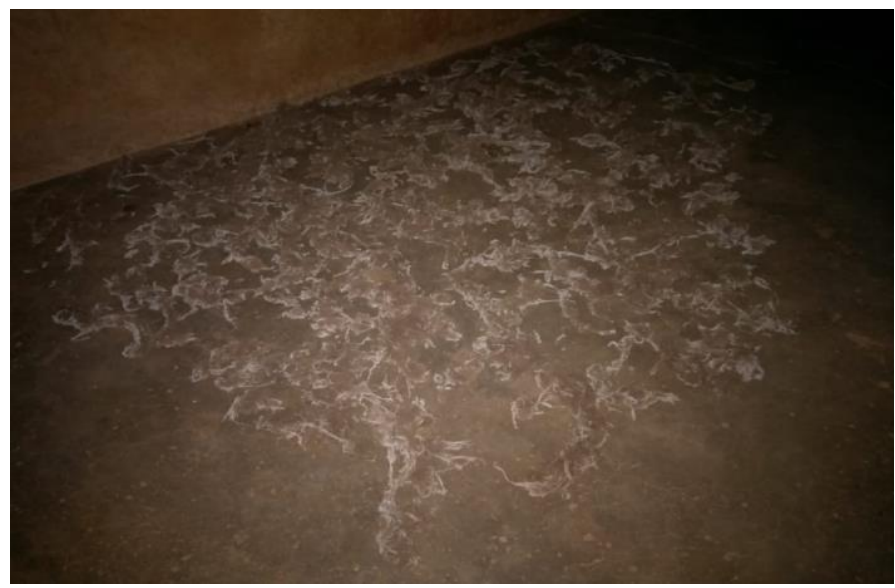

5: Drying of sesame of sesamum mucilage

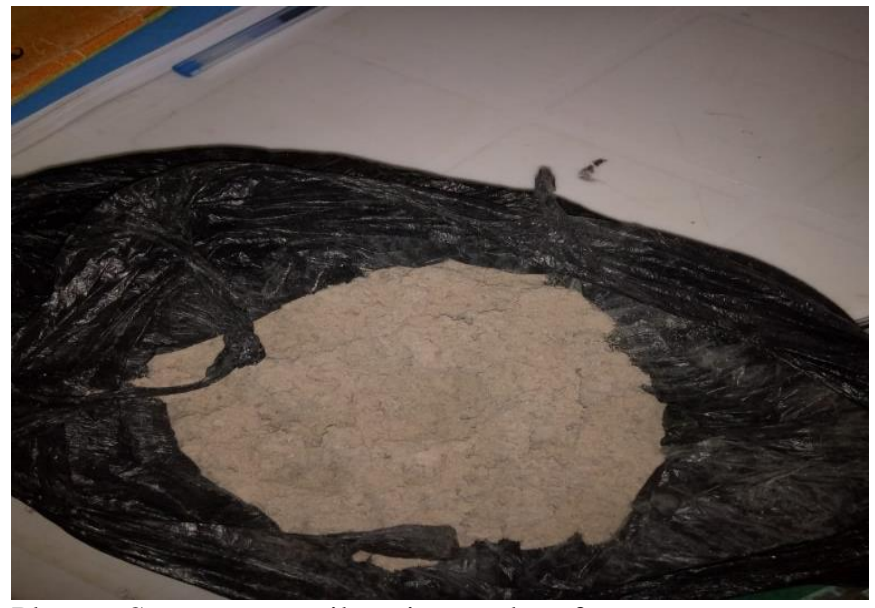

Plate 6: Sesamum mucilage in powdery form

\section{REFRENCES}

1. Akeke, G. A., Ewa, D. E., \& Okafor, F. O. (2016). Effects Of Variability In The Pozzolanic Properties Of Rice Husk Ash On The Compressive Strength Of
Concrete. Nigerian Journal of Technology (NIJOTECH), (pp. 694-698).

2. Shetty, M. S. (2005). Concrete Technology Theory and Practice. New Delhi, India: S Chand and Company Ltd.

3. Punkki, J. (2018). Finland: Aalto University School of Engineering Department of Civil Engineering.

4. Benjamin, E. O., \& Peter, O. (2015). The Use of Gum Arabic as an Admixture in Concrete. Scholars Journal of Engineering and Technology (SJET), (pp.282-292).

5. Nemati, K. M. (2015). Concrete Technology. Washington: Winter Quarter, University Of Washington.

6. Abd, S. M., Hamood, Q. Y., Khamees, A. S., \& Ali, Z. H. (2016). Effect Of Using Corn Starch As Concrete Admixture. International Journal of Engineering Resarch And Science And Technology.

7. Shah, D. S., Shah, M. P., and Pitroda, J. (2014). Chemical Admixtures: A Major Role In Modern Concrete Materials And Technologies. National Conference on: "Trends and Challenges of Civil Engineering in Today's Transforming World". Civil Engineering Department S.N.P.I.T. \& R.C., Umrakh.

8. Zeyad, A. M., Tayeh, B. A., Saba, A. M., and Johari, M. M. (2018). Workability, Setting Time and Strength of High-Strength Concrete Containing High Volume of Palm Oil Fuel Ash. The Open Civil Engineering Journal, (pp.35-46).

9. Sanchez, M. A., Molina, W. M., Guzman, E. A., Garcia, H. C., Acosta, A. T., Reyes, C. B., and Ruiz, R. R. (2015). Effect of the Addition of Dried Opuntia Cactus Fibers - Setting Times and Mechanical Resistance in Portland Cement Mortar Base. 2nd International Conference on Green Materials and Environmental Engineering. Mexico.

10. Hansen, R. (2011). Sesame Profile.

11. NAERLS. (2010). Beniseed Production And Utilisation In Nigeria. Extension Bulletin.

12. Osemeahon, S. A., Hamma'Adama, M. A., Kolo, A. M., \& Opara, I. J. (2017). Evaluation Of Sorption Behavior Of Immobilized Karkashi Leaves(Sesamum Indicum) $\mathrm{On} \mathrm{Pb} 2+, \mathrm{Cu} 2+$ And $\mathrm{Zn} 2+\mathrm{In}$ Aqueous 
Solution. International Journal of Scientific \& Technology Research, 278.

13. Jospeh, H. (2009). Nigeria: Boosting Benue's Beniseed Potential. Nigeria: Daily Trust Newspaper.

14. CBN. (2009). Annual Report And Statement Of Account For The Year Ended 31st December 2008.

15. British Standard, (1993). Testing concrete; Method for determination of compacting factor. BS 1881103, BSI, Linfordwood, Milton Keynes MK14 6LE, U.K.

16. British Standard, (1983). Testing concrete; Method for determination of slump. BS 1881-102, BSI, Linfordwood, Milton Keynes MK14 6LE, U.K.

17. British Standard European Norm, (2002). Testing hardened concrete; Compressive strength of test. $B S$ EN 12390-3, BSI, Linfordwood, Milton Keynes MK14 6LE, U.K.

18. British Standards, BS 1881 Part 4, Method of Testing Concrete for Strength (London: British Standard Institution BSI, 1970).

19. Neville, A. M. (1997). Properties of concrete, New York: John Wiley \& Sons.

20. ENV206. (1992). concrete quality assurance and conformity of concrete. Brussels: European Committee for Standardization.

21. Neville, A.M. and Brooks, J.J., (2010). Concrete Technology. 2nd edition. Long man Group United Kingdom Limited, (pp. 30-269).

22. Chindaprasirt, P., Homwuttiwong, S. and Sirivivatnanon, V., (2004) "Influence of fly ash fineness on strength, drying shrinkage and sulfate resistance of blended cement mortar," Cement and Concrete Research, vol. 34, no. 7, (pp. 1087-1092). 